\title{
Microgram per Gram per Minute
}

National Cancer Institute

\section{Source}

National Cancer Institute. Microgram per Gram per Minute. NCI Thesaurus. Code

C74923.

A dose calculation unit expressed in microgram(s) per gram per period of time equal to sixty seconds. 